\title{
Impact of Drought on the Intra-Annual Growth of Pinus sylvestris L.
}

\author{
L. Fernández-de-Uña ${ }^{*}, 1$, P. Fonti ${ }^{2}$, I. Aranda ${ }^{3}$, I. Cañellas ${ }^{1}$ and G. Gea-Izquierdo ${ }^{1,4}$ \\ ${ }^{I}$ Department of Silviculture and Management of Forest Systems, INIA-CIFOR, Spain \\ ${ }^{2}$ Swiss Federal Research Institute WSL, Switzerland \\ ${ }^{3}$ Department of Forest Ecology and Genetics, INIA-CIFOR, Spain \\ ${ }^{4} C E R E G E-C N R S$, France
}

\begin{abstract}
Climatic scenarios for the Mediterranean Region forecast increasing frequency and intensity of drought events. We analyzed how Pinus sylvestris modifies its cambial phenology and intra-annual growth under enhanced drought conditions. For this purpose, a rainfall exclusion experiment was applied in 2012 to trees located in the lower elevation limit of a mountain forest in Central Spain. Preliminary results show a significantly longer growing season in small trees than in big trees, regardless of the treatment. The tracheid enlargement period was longer in control trees than in trees subjected to rainfall exclusion regardless the size class. Cambial activity and gas exchange rates of Pinus sylvestris responded immediately to drier conditions, which could indicate vulnerability to drought enhancement. Stronger differences between treatments are expected for the second year of the experiment due to the cumulative effect of drought in the rainfall exclusion plots.
\end{abstract}

Keywords: Cambial phenology, gas exchange, global warming, rainfall exclusion, vulnerability, xylogenesis.

\section{INTRODUCTION}

Rising temperatures and stable or decreasing precipitations, as expected under climate change scenarios for the Mediterranean region, will likely increase the frequency and intensity of drought events [1]. Changes in forest productivity [2], tree phenology [3] and species distribution, both in latitude [4] and altitude [5], have been observed as a result of climate warming.

Pinus sylvestris L. is a Eurosiberian species which southern distribution limit is found in the mountain ranges of the Iberian Peninsula. With climate change, this species is expected to reduce its current distribution range, being likely displaced at low altitudes by more drought tolerant taxa like Quercus spp. [6].

In this study we characterized how $P$. sylvestris will respond to increasing drought and analyzed how enhanced drought conditions affect the cambial phenology and the intra-annual growth of $P$. sylvestris growing at its local lower elevation limit.

\section{MATERIALS AND METHODS}

The sampled trees were located in Valsaín (Central Spain, $40^{\circ} 51^{\prime} 35^{\prime \prime} \mathrm{N}, 4^{\circ} 3$ ' $52^{\prime}$ ' W), at an altitude of 1350 m.a.s.l. at the transition zone between Pinus sylvestris L.and Quercus pyrenaica Willd.-dominated woodlands. These

*Address correspondence to this author at the Departamento de Selvicultura y Gestión de los Recursos Forestales, INIA-CIFOR, Ctra. La Coruña, km 7,5, 28040 Madrid, Spain; Tel: +34 913476853; Fax: +34 913476767;

E-mails: fernandez.laura@inia.es, laura.fernandezdeuna@gmail.com species do not mix uniformly, being distributed in small patches within the stand. Mean annual precipitation is 900 $\mathrm{mm}$ and the mean annual temperature $9{ }^{\circ} \mathrm{C}$. Given the existing bimodal diameter distribution in the pine stand we differentiated two size categories: small trees $(<30 \mathrm{~cm} \mathrm{dbh})$ and big trees $(>30 \mathrm{~cm})$. In April 2012, a rainfall exclusion experiment was established for each species and size class. Soil was covered with PVC boards and a $0.5 \mathrm{~m}$ ditch was dug on the upper side of the slope to minimize subsurface water flow. Soil humidity sensors were set at each exclusion plot and in the control area. Site characteristics were similar in both treatment and control areas.

Micro-cores were sampled every 7-10 days between April and October 2012 from six trees per treatment (three from large trees and three from small trees). Samples were extracted with a Trephor $^{\circledR}$ [7] and conserved in a $50 \%$ ethanol solution. In the laboratory, micro-cores were changed to a $70 \%$ ethanol solution and stored at $4{ }^{\circ} \mathrm{C}$ until they were cut with a sliding microtome. Sections were stained with safranine and astrablue, dehydrated with increasing concentrations of ethanol and xylol, and embedded in Canada balsam. The number of tracheids in each phase (cambium, enlargement, wall-thickening and mature) was counted in three segments per date and averaged. The average number of tracheids of the previous year was used as a control. To standardize the results and avoid bias due to differences in growth between trees, the total number of tracheids of the current year was divided by the average number of tracheids of the previous year.

In addition, gas exchange was recorded in June, August and September. Measurements were performed on currentyear needles exposed to direct sunlight with an $\mathrm{LCpro}^{+}$ 
portable photosynthesis system on three trees per size category and treatment, in the morning and in the afternoon. A subsample of the measured needles was scanned to measure their areas. All needles were dried and weighed. Specific leaf area was then calculated in order to obtain the photosynthetic rate (A), transpiration rate (E) and stomatal conductance $\left(\mathrm{g}_{\mathrm{s}}\right)$ on a leaf area basis, together with water use efficiency (WUE).

Boxplots were used to graphically compare data. Given the small sample size with a non-normal distribution, Kruskal-Wallis one-way analysis of variance was used to statistically assess the differences between treatments and size-classes.

\section{RESULTS AND DISCUSSION}

The year 2012 was abnormally dry and warm, with precipitations being about $25 \%$ lower and temperatures up to $2{ }^{\circ} \mathrm{C}$ warmer than the average [8]. Additionally, average soil moisture was reduced by $10 \%$ in the rainfall exclusion plots.

The number of tracheids counted over the growing season separated by each cell phenological phase and for big and small trees are shown in Figs. $(\mathbf{1}, \mathbf{2})$, respectively. Small trees had a significantly longer growing season than big trees (32 days on average), regardless the treatment ( $p$ value $=0.0039$ ). This pattern was found for all phases. The tracheid enlargement period was on average longer in control trees than in trees subjected to rainfall exclusion for both tree sizes, although this was non-significant. Shorter growing seasons in older ages have been similarly reported in other studies [9, 10].

No significant differences were found between treatments in the total number of tracheids formed for any of the tree sizes. However, the ratios between the total number of tracheids of the current and the previous year showed differences between treatments and tree sizes. Small trees had a lower response to the 2012 drought than big trees (ratios $0.71 \pm 0.15$ vs $0.55 \pm 0.12$, respectively). Furthermore, control trees had higher ratios than treated trees.

Regarding gas exchange measurements, the effect of rainfall exclusion was more evident in August, when, considering both tree sizes together, significant differences between control and treated trees were found for A, E, $g_{s}$ and WUE for the afternoon measurements (Table 1). This effect of drought on leaf gas exchange is consistent with studies in Mediterranean species [11], and it is a result of stomatal closure to prevent xylem embolism [12].

The lack of significant differences between treatments in the timing of xylogenesis and total tracheid production in this first year may be explained by the small differences in water availability between control and rainfall exclusion plots due to the 2012 drought and by the late establishment

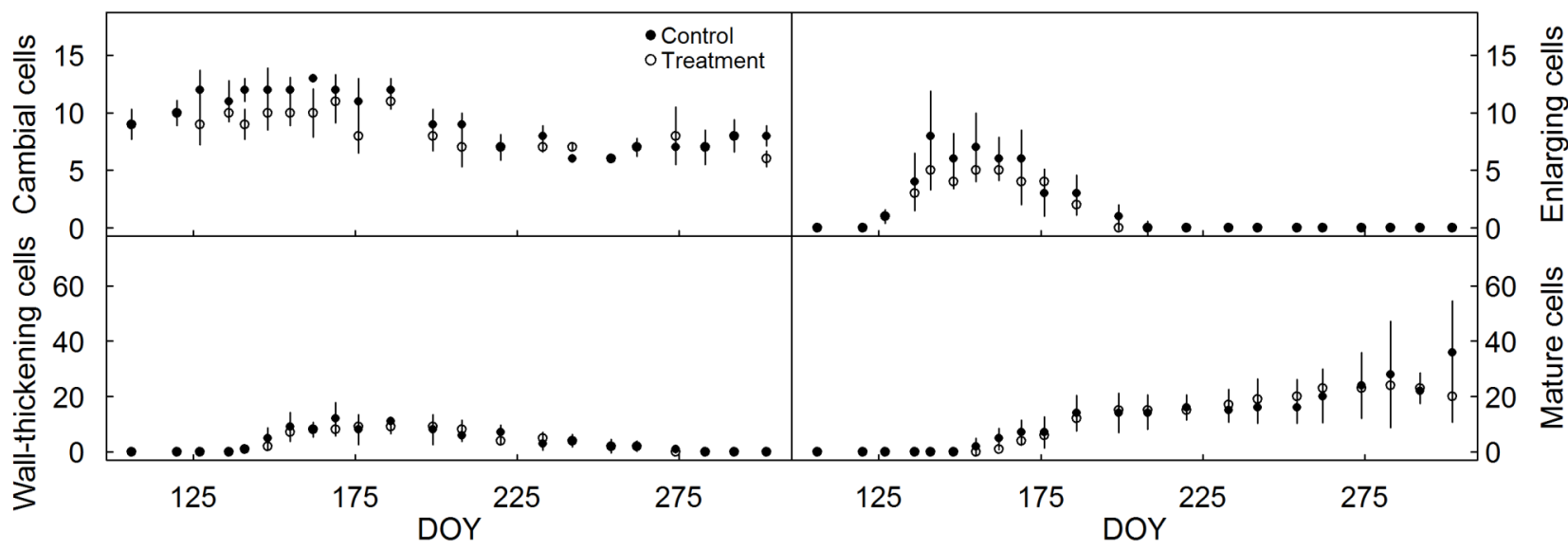

Fig. (1). Number of tracheids in the different phases at the different sampling dates (DOY: day of year) for big trees.

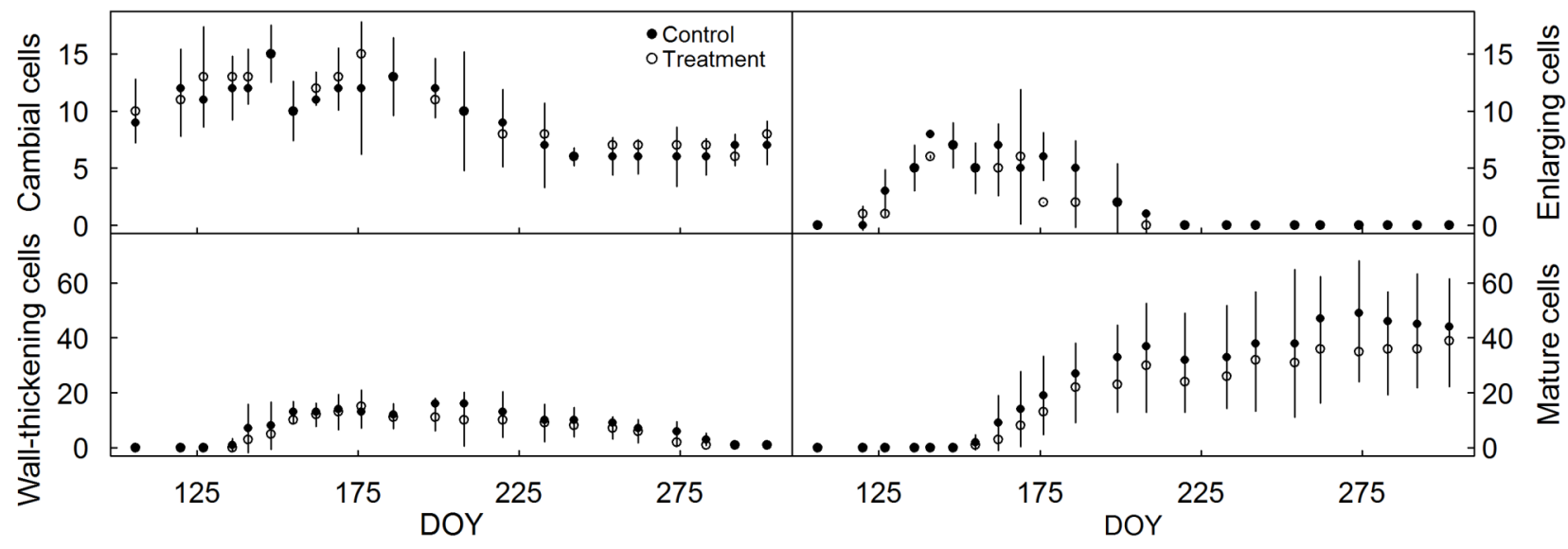

Fig. (2). Number of tracheids in the different phases at the different sampling dates (DOY: day of year) for small trees. 
Table 1. Mean Values of Photosynthetic Rate (A; $\left.\mu \mathrm{mol} \mathrm{CO}_{2} \mathrm{~m}^{-2} \mathrm{~s}^{-1}\right)$, Transpiration Rate $\left(\mathrm{E} ; \mathrm{mmol}_{\mathbf{2}} \mathrm{O} \mathrm{m}^{-2} \mathrm{~s}^{-1}\right)$, Stomatal Conductance $\left(\mathrm{g}_{\mathrm{s}} ; \mathrm{mmol} \mathrm{H}_{2} \mathrm{O} \mathrm{m}^{-2} \mathrm{~s}^{-1}\right.$ ) and Water Use Efficiency (WUE; $\mu \mathrm{mol} \mathrm{CO} \mathrm{Cmol}^{-1} \mathrm{H}_{2} \mathrm{O}$ ) at the Different Sampling Dates Separated by Size and Treatment and Time of the Day. BC: Control Big Trees; BE: Treated Big Trees; SC: Control Small Trees; SE: Small Treated Trees; M: Morning Measurement; Af: Afternoon Measurement

\begin{tabular}{|c|c|c|c|c|c|c|c|c|c|c|c|c|c|c|c|c|c|c|c|c|c|c|c|c|}
\hline & \multicolumn{8}{|c|}{ June } & \multicolumn{8}{|c|}{ August } & \multicolumn{8}{|c|}{ September } \\
\hline & \multicolumn{2}{|c|}{ BC } & \multicolumn{2}{|c|}{ BE } & \multicolumn{2}{|c|}{ SC } & \multicolumn{2}{|c|}{ SE } & \multicolumn{2}{|c|}{ BC } & \multicolumn{2}{|c|}{ BE } & \multicolumn{2}{|c|}{ SC } & \multicolumn{2}{|c|}{ SE } & \multicolumn{2}{|c|}{ BC } & \multicolumn{2}{|c|}{ BE } & \multicolumn{2}{|c|}{ SC } & \multicolumn{2}{|c|}{ SE } \\
\hline & M & Af & $\mathbf{M}$ & Af & M & Af & $\mathbf{M}$ & Af & $\mathbf{M}$ & Af & $\mathbf{M}$ & Af & $\mathbf{M}$ & Af & $\mathbf{M}$ & Af & $\mathbf{M}$ & Af & $\mathbf{M}$ & Af & $\mathbf{M}$ & Af & $\mathbf{M}$ & Af \\
\hline $\mathbf{A}$ & 1.9 & 2.1 & 1.0 & 2.3 & 2.5 & 3.1 & 3.4 & 3.7 & 8.4 & 8.8 & 5.4 & 3.7 & 9.5 & 7.5 & 9.5 & 6.1 & 8.2 & 4.9 & 3.9 & 4.0 & 4.0 & 2.7 & 3.9 & 3.5 \\
\hline $\mathrm{gs}_{\mathrm{s}}$ & 52 & 34 & 53 & 28 & 56 & 57 & 76 & 39 & 59 & 55 & 31 & 21 & 35 & 59 & 72 & 38 & 43 & 25 & 22 & 17 & 21 & 13 & 22 & 18 \\
\hline $\mathbf{E}$ & 2.7 & 1.7 & 2.5 & 1.4 & 2.1 & 2.2 & 2.0 & 1.6 & 1.8 & 3.0 & 1.4 & 0.9 & 1.8 & 2.9 & 2.5 & 1.5 & 1.0 & 0.5 & 0.5 & 0.5 & 0.5 & 0.3 & 0.4 & 0.4 \\
\hline WUE & 0.7 & 1.5 & 0.5 & 1.8 & 1.2 & 1.4 & 2.0 & 2.3 & 4.8 & 3.4 & 3.9 & 4.1 & 5.0 & 2.7 & 3.7 & 4.0 & 8.5 & 11.1 & 8.8 & 7.8 & 9.1 & 10.4 & 9.6 & 8.9 \\
\hline
\end{tabular}

of the exclusion plots in spring. Thus, trees profited from part of spring precipitation. This problem is common in mountainous areas where plots are not easily accessible in winter [13]. Nonetheless, the clearer effect of rainfall exclusion in ecophysiological measurements than in xylogenesis show that photosynthetic activity has a faster response to drought than xylem formation, which depends not only on the current year's uptake but on the tree's carbohydrate pool [14].

The observed Pinus sylvestris cambial activity and ecophysiological response to drier conditions could indicate vulnerability to drought in its lower elevation limit. Stronger differences between treatments in xylogenesis are expected during the second year of the experiment, as a result of the cumulative impact of drought in the rainfall exclusion plots. These longer data series will also allow us to study the relationship between $P$. sylvestris intra-annual growth and climate and compare it to that of Quercus pyrenaica, the other co-dominant species in the studied woodland.

\section{CONFLICT OF INTEREST}

The authors confirm that this article content has no conflict of interest.

\section{ACKNOWLEDGEMENTS}

The authors thank the Spanish Ministry of Economy and Competitiveness for funding the project AGL2010-21153C02-01. We also thank L. Schneider, E. Viscasillas, A. Bachiller and A. Parras for field and laboratory assistance.

\section{REFERENCES}

[1] IPCC. Climate Change 2007: The Physical Science Basis. Contribution of Working Group I to the Fourth Assessment Report of the Intergovernmental Panel on Climate Change. In: Solomon S,
Qin D, Manning M, et al., Eds. NY, USA: Cambridge University Press, Cambridge, United Kingdom and New York 2007.

[2] Sarris D, Christodoulakis D, Körner C. Recent decline in precipitation and tree growth in the eastern Mediterranean. Glob Change Biol 2007; 13(6): 1187-200.

[3] Menzel A, Sparks TH, Estrella N et al. European phenological response to climate change matches the warming pattern. Glob Change Biol 2006; 12(10): 1969-76.

[4] Thuiller W, Lavorel S, Aráujo MB, Sykes MT, Prentice IC Climate change threats to plant diversity in Europe. Proc Natl Acad Sci USA 2005; 102(23): 8245-8250.

[5] Lenoir J, Gégout JC, Marquet PA, De Ruffray P, Brisse H. A significant upward shift in plant species optimum elevation during the 20th century. Science 2008; 320(5884): 1768-71.

[6] Ruiz-Labourdette D, Nogués-Bravo D, Ollero HS, Schmitz MF, Pineda FD. Forest composition in Mediterranean mountains is projected to shift along the entire elevational gradient under climate change. J Biogeogr 2012; 39(1): 162-76.

[7] Rossi S, Anfodillo T, Menardi R. Trephor: a new tool for sampling microcores from tree stems. IAWA J 2006; 27(1): 89-97.

[8] AEMET. Resumen Anual Climatológico 2012. Ministerio de Agricultura, Alimentación y Medio Ambiente. 2012 [cited 2013 March 4]. Available from http://www.aemet.es/documentos/es/ser viciosclimaticos/vigilancia_clima/resumenes_climat/anuales/res_an ual_clim_2012.pdf

[9] Li X, Liang E, Gričar J, Prislan P, Rossi S, Čufar K. Age dependence of xylogenesis and its climatic sensitivity in Smith fir on the south-eastern Tibetan Plateau. Tree Physiol 2013; 33(1): 4856.

[10] Rossi S, Deslauriers A, Anfodillo T, Carrer M. Age-dependent xylogenesis in timberline conifers. New Phytol 2008; 177(1): 199208.

[11] Limousin JM, Rambal S, Ourcival JM, Rocheteau A, Joffre R, Rodriguez-Cortina R. Long-term transpiration change with rainfall decline in a Mediterranean Quercus ilex forest. Glob Change Biol 2009; 15(9): 2163-75.

[12] Irvine J, Perks MP, Magnani F, Grace J. The response of Pinus sylvestris to drought: stomatal control of transpiration and hydraulic conductance. Tree Physiol 1998; 18(6): 393-402.

[13] Belien E, Rossi S, Morin H, Deslauriers A. Xylogenesis in black spruce subjected to rain exclusion in the field. Can J For Res 2012; 42: 1306-15.

[14] Hoch G, Richter A, Körner C. Non-structural carbon compounds in temperate forest trees. Plant Cell Environ 2003; 26: 1067-81. 